\title{
Harrison R. Crandall: Artist, Pioneer and Patron of Grand Teton National PARK
}

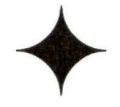

KENNETH A. BARRICK $\downarrow$ UNIVERSITY OF ALASKA $\downarrow$ FAIRBANKS

\section{$\downarrow \quad$ INTRODUCTION}

Harrison R. Crandall (or "Hank" as he preferred; Fig. 1) is best known for his paintings and photographs of the Teton Range, and ranch scenes of Jackson Hole, Wyoming. However, Hank's multi-faceted life, which spanned the period from 1887-1970, was far more interesting and important than is generally recognized. He was the first artist and commercial photographer to operate a studio in the Jackson Hole area, but he was also a valley homesteader, an important

Grand Teton National Park, and a pioneer concessionaire of National Park art and souvenirs before the advent of mass tourism. Hank's natural artistic talent was accompanied by a complex personality - a mixture of the spirited individualism required of a mountain adventurer and dry-land homesteader, a loving and dedicated family man who promoted shared labor and leisure, and an environmentally attuned visionary who helped many to interpret the meaning of the Grand Teton National Park experience.
\end{abstract} supporter and patron in the establishment of the

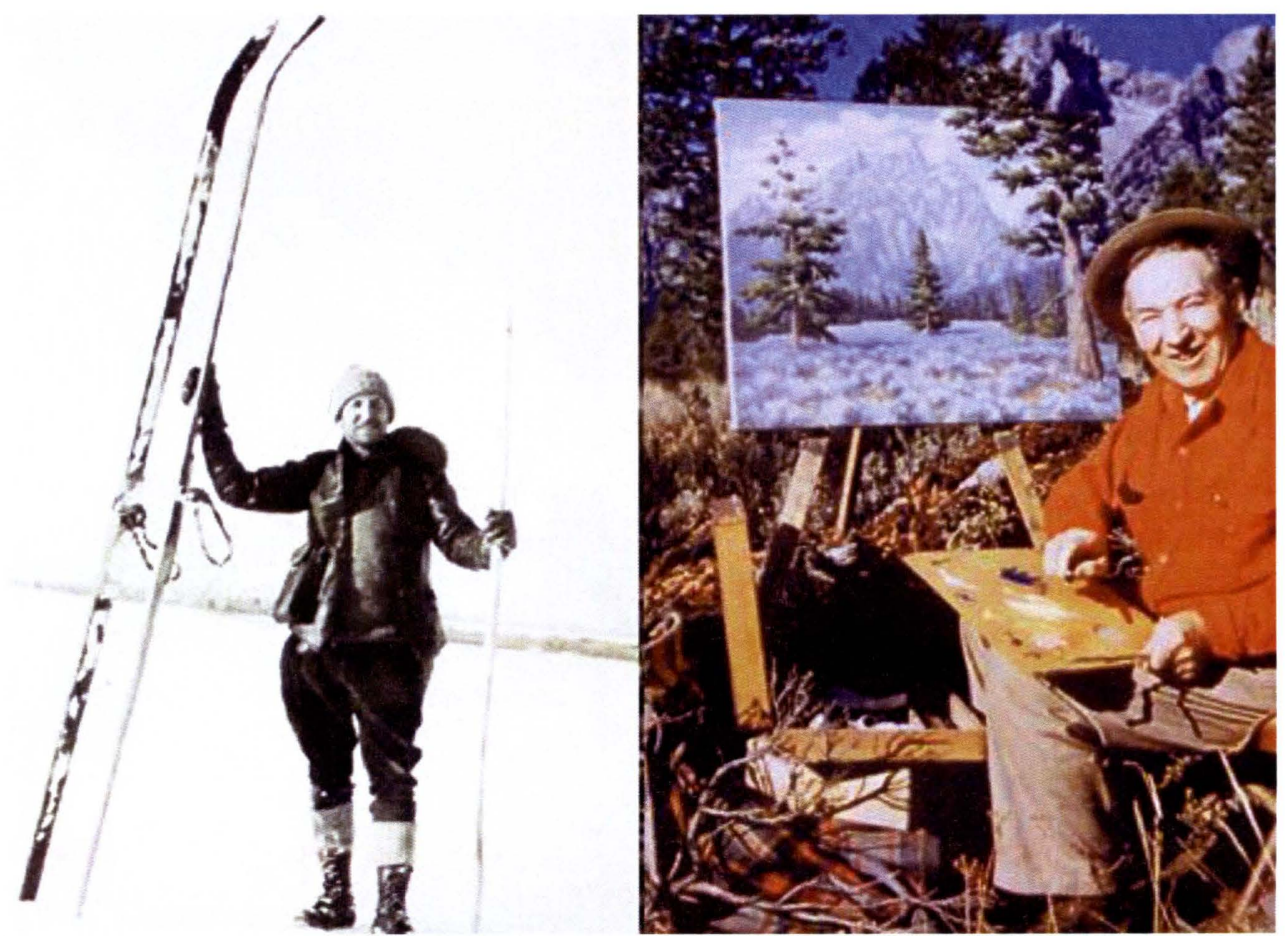

Figure 1. Hank Crandall with his skis ca. mid-1920's (left), and Hank painting the Tetons ca. 1950 (right) (C Crandall) 


\section{- Hank Crandall's Art-Photographs and Oil Paintings}

Hank's artistic and technical expressions were the result of a unique combination of his personal vision, early $20^{\text {th }}$ Century academic conventions, and the equipment, emulsions, and chemistry that was available at the time (H. Pownall, 1991; H. Pownall, personal communication 2008 ). Photography was a staple of the Crandall Studio business. Hank had the ability to capture the photographs that people wanted as remembrances of their Teton experience, and many of these subjects have become the iconic images of Jackson Hole (Fig. 2). His favorite subjects included Teton landscapes (Fig. 3), wildflowers, Native Americans, and western life style scenes complete with buck-rail fences, cowboys and cowgirls (Flood 1996; Q. Pownall, personal communication 2008).
Hank's vision of the Jackson Hole landscape resulted in photographs with luminous mountains and a bright sky (Pownall, 1991). Hank was most proud of his hand painted wildflower panels (Fig. 4), and Native American portraits (Fig. 5) (Crandall, Hildegard 1970). Today, the strong secondary market for Hank's photographs is explained, in part, by the consistently high quality of his photographic prints. Hank demanded quality in the field and the darkroom, which is best explained by his own words, "It is my aim and ambition to only turn out the best pictures that are possible to be made, as I figure a poor picture is worse than nothing" (Flood 1996). In the darkroom, large and expensive prints were torn up if they were not just right (H. Pownall, personal communication 2007).

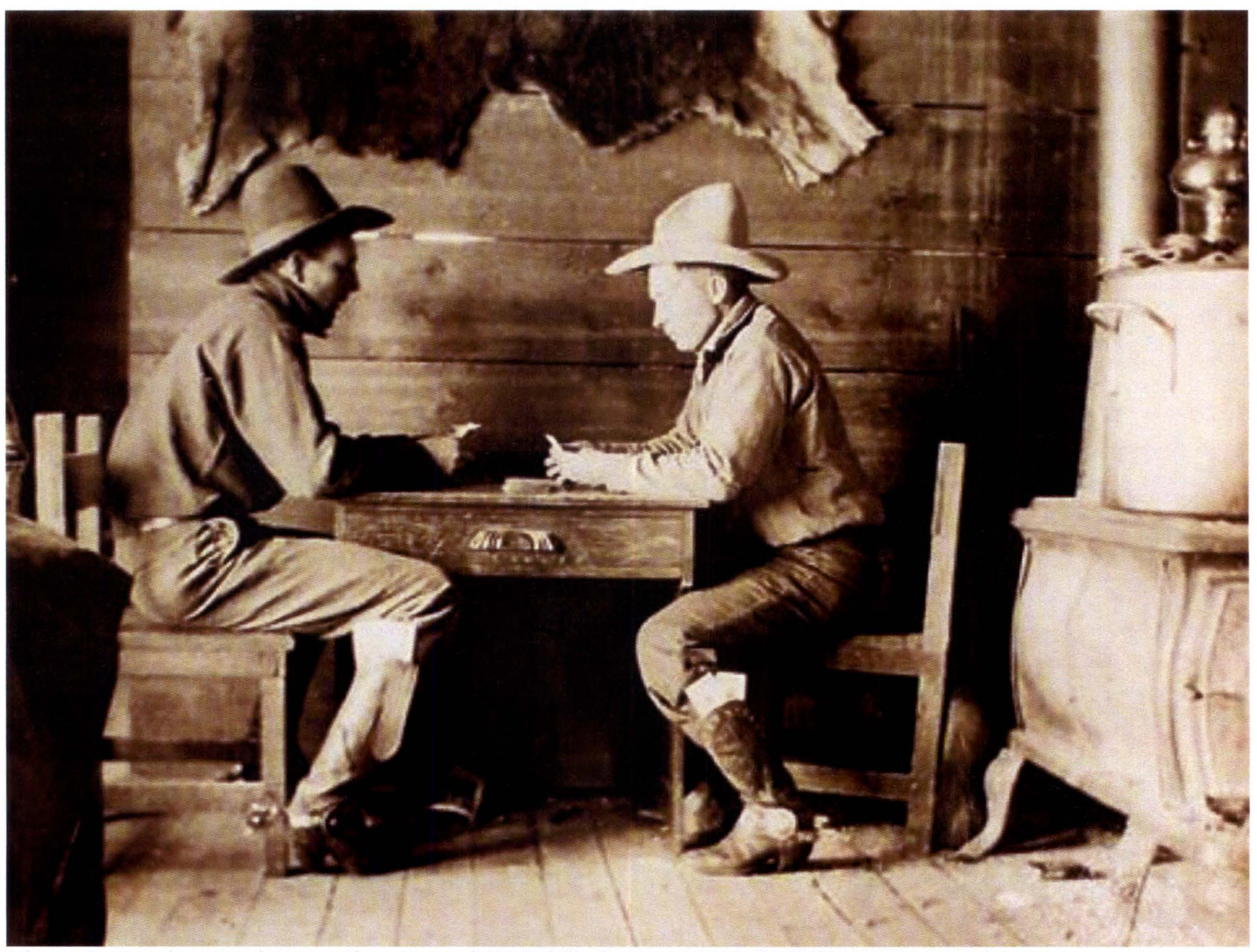

Figure 2. Cowboy Pastime — an iconic Hank Crandall photograph of ranch life in Jackson Hole (C Crandall) 

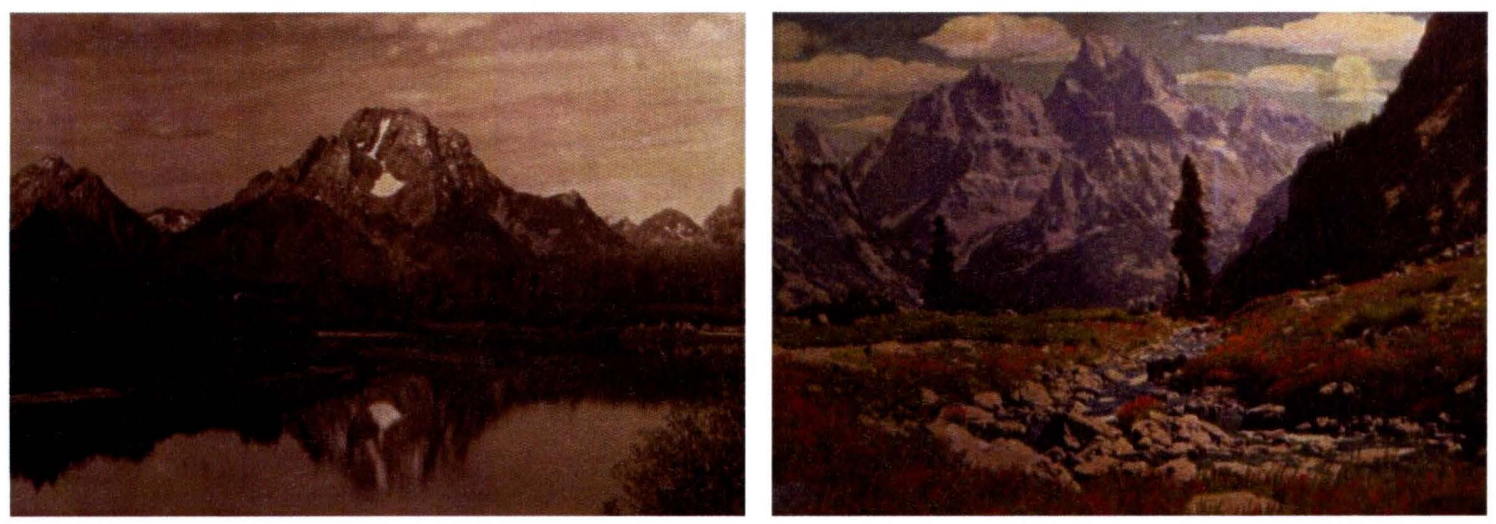

Figure 3. Hank Crandall Teton landscapes - Sepia-tone photograph of Mount Moran (left), and hand painted photograph, "North View of the Grand Teton" (right)
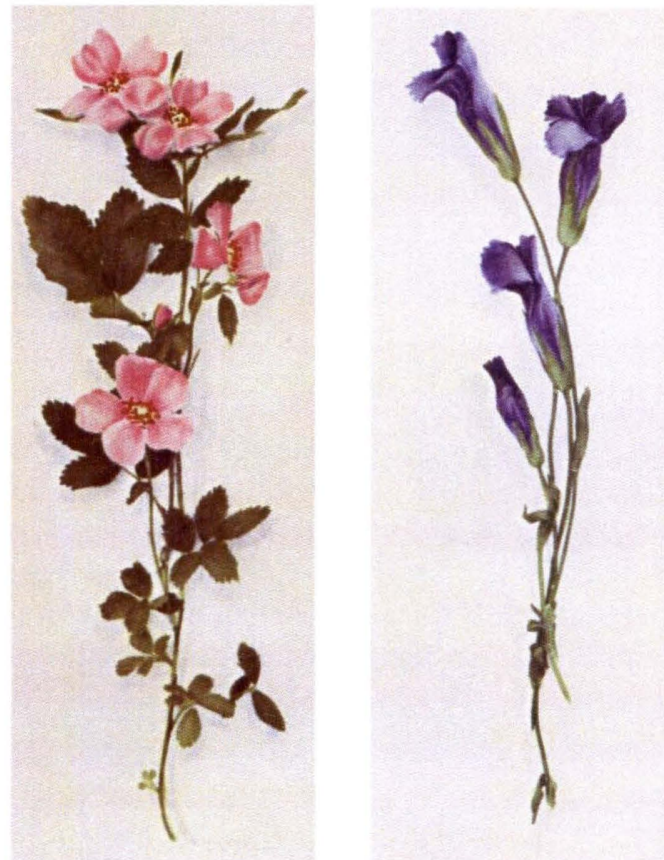

Figure 4. Hank Crandall hand painted, wildflower panel photographs-"Wild Rose" (left), and "Fringed Gentian" (right).

Hank used a variety of camera types, and a wide range of film sizes-from small to large formats. His favorite equipment included panel cameras for sheet film. Negative sizes ranged from $3 \frac{1}{4} \times 4 \times \frac{1}{4}$, through $4 \times 5,5 \times 7,8 \times 10$ and $7 \times 17$ inches. The $3 \mathrm{~A}$ Kodak roll film size was right for contact prints on post card stock paper. He also used $16 \mathrm{~mm}$ and $35 \mathrm{~mm}$ roll films $(\mathrm{H}$. Pownall 1991; H. Pownall personal communication 2008). Many of Hank's photographs from the 1920 s and 1930s were made on orthochromatic emulsions, which was the type of film that was available to him. Orthochromatic film was considered to be "color

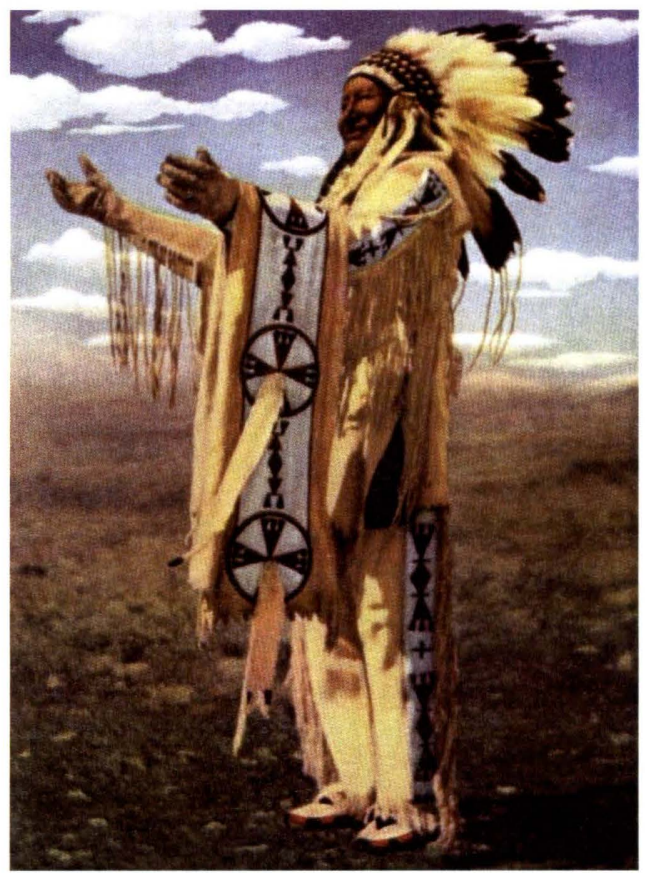

Figure 5. Hank Crandall hand painted photo-Native American (C) Crandall

blind" in the sense that a scene was recorded in gray tones that were different from what the eye sees. The film was more sensitive to blue than red, which produced a very light sky. Hank occasionally used lens filters when photographing with panchromatic films, but he preferred not to try for the artificial effects that filters tended to generate $(\mathrm{H}$. Pownall 1991; $\mathrm{H}$. Pownall personal communication 2008).

During print exposure, Hank's dodging and burning-in patterns required the nimble hands of an orchestra conductor-he sought the precise emphasis that would achieve his scenic 
vision (H. Pownall, 1991; H. Pownall personal communication 2008). The process of creating a hand painted photo began with a photographic print made on single-weight Kodak mural paper that was deliberately underexposed in order to render it to about 25 percent of the contrast and density of a normal black and white photo. The lighter image allowed the opaque color oils to be more easily superimposed over top of the photographic image (H. Pownall personal communication 2008). While many photographers produced hand tinted photos before the advent of color films, Hank's color applications were unique. The photographs were heavily over-painted with vivid oil colors - in a sense, the underlying photographic image was treated like the canvas of an oil painting.

Painting the Teton Range was always foremost among Hank's artistic goals. The great majority of Hank's oil paintings were Teton landscapes (Fig. 6). However, proving up the homestead, creating and running an art studio, and raising a family consumed much of Hank's time. Therefore, many of his oil paintings were completed after his retirement from the Crandall Studio business. It was during these more tranquil moments that Hank was able to focus on evolving his technique, and the style of his paintings shifted from realism to a more subjective vision (Q. Pownall personal communication 2007). Hank's paintings were very popular, and continue to grace many homes in Jackson Hole (Jackson Hole News \& Guide 2006; Winchell 2007), and they were distributed across the United States as National Park souvenirs.

\section{$\downarrow$ Hank Crandall as Patron of the Grand Teton National Park}

Hank considered the Teton Range to be his "ideal landscape" - a place that he loved, and a landscape with the power to cause him to move his family in order to fully live the Teton experience. Some suggest that Hank surrendered some of the national notoriety that he might otherwise have achieved in order to remain focused on his Teton art despite the lack of a mass market for the subject at the time. Given Hank's deep commitment to the Tetons, it is easy to understand why he was an ardent supporter of establishing the Grand Teton National Park. Hank was the Park's greatest publicist-he was to the Teton Range and Jackson Hole what F.J. Haynes was to Yellowstone National Park (NPS 2007). Many of Hank's photographs were gifted to the Grand Teton National Park for promotional purposes (Fig. 7). Hank's photographs helped sway the U.S. Congress into establishing the Park (Jackson Hole News \& Guide 2006). Moreover, with the agreement to sell their homestead, the Crandall's transferred a key property for the creation of the preserve. Horace M. Albright, the Director of the National Park Service at the time that the Grand Teton National Park was dedicated, commented on Hank's commitment to the Park ideal, "Hank Crandall never wavered in his adherence to plans, including the creation of a Grand Teton National Park, to preserve the best of Jackson Hole for present and future generations" (Albright 1971).
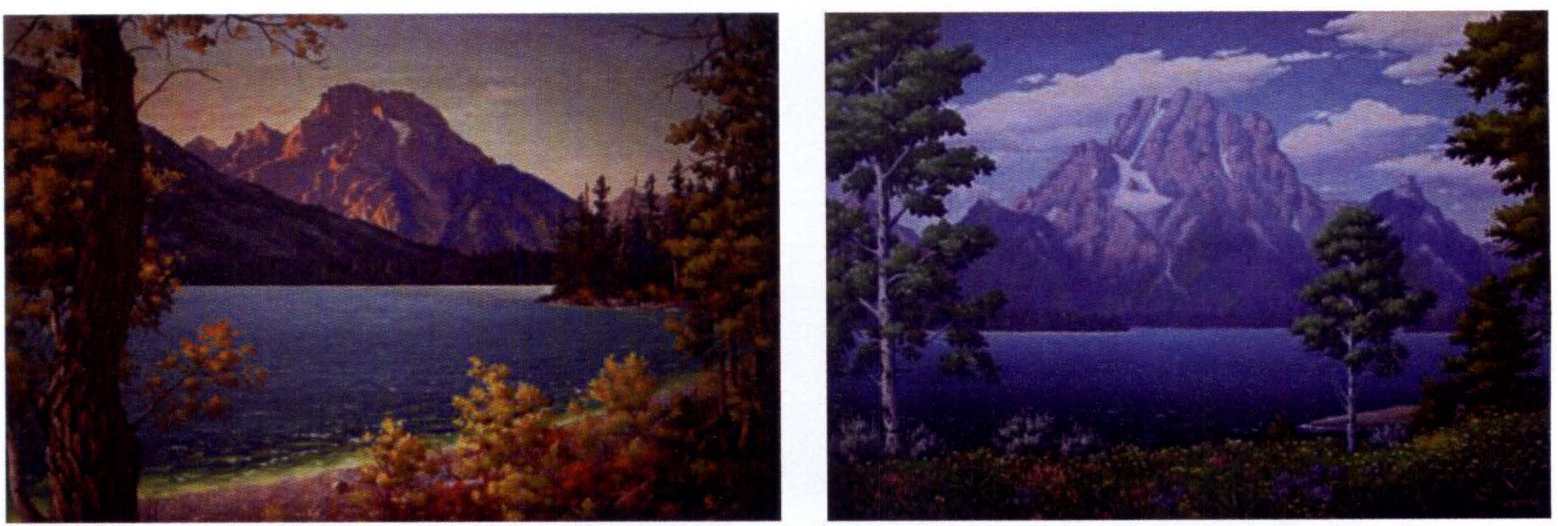

Figure 6. Hank Crandall oil paintings of Mount Moran — early painting ca. 1930's (left), late painting ca. 1960 's (right). 


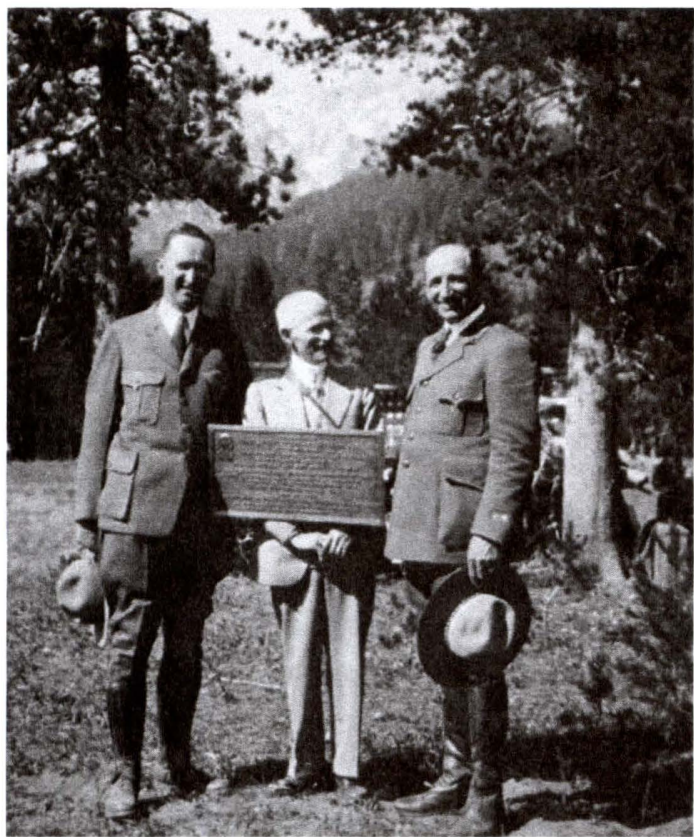

Figure 7. Hank Crandall photo of Grand Teton National Park dedication ceremony-Horace Albright, Director of the National Park Service (left), Billy Owen, famous climber of the Grand Teton (center), and Park Superintendent Sam Woodring (right) (C) Crandall)

\section{$\downarrow$ Hank Crandall-Life and Times}

Hank Crandall was born on 23 November 1887, in Newton, Kansas, to Sarah Conover Crandall and Robert Wyatt Crandall (Crandall and Crandall 1976). He was the ninth of ten children (Q. Pownall 1991). Hank's father ran a nursery and berry farm on the plains of Kansas despite having lost his arm while serving in the Union Army during the Civil War.

Hank began dreaming of westward travel and adventure at an early age. In grade school, he was inspired by the landscape photographs found on the pages of his geography textbooks. In particular, he recalled a picture of the Teton Range by William Henry Jackson. Hank resolved to visit those seemingly distant mountains (Crandall, Hildegard 1970).

The opportunity to move west came at the age of 25, when Hank's brother filed for a homestead in the sand hills of Idaho. Hank was sent to sit on the claim. He traveled to Idaho on a freight train, which was carrying a Kansas family's household goods. Hank was allowed the price of the train fare in return for feeding and milking the family's cow along the route (Crandall and Crandall 1976). He lived in a shanty on the claim for little more than 3 months until the land was deemed worthless for farming (Crandall and Crandall, 1976). After abandoning his brother's claim, Hank moved to Los Angeles, California, and begin his formal art training. He enrolled at the School of Art and Design, where he studied for several years (Crandall and Crandall, 1976; Crandall, Hildegard 1970). Hank took on several jobs to defray the cost of his education, including painting theatre backdrops and murals. During his summer vacation, he lived at Lake Tahoe, where he played trombone in a local dance band (Crandall and Crandall, 1976; Q. Pownall, personal communication 1991).

Hank served in the Navy Band during World War I. After the war, he moved to American Falls, Idaho, where he met his future wife-Hildegard R. Winter (Hilda as Hank preferred; Fig. 8). She was born on 27 April 1898, at Menno, South Dakota. In 1911, her family moved to a homestead west of American Falls. After secretarial school, she went to work for a local bank (Crandall and Crandall 1976).

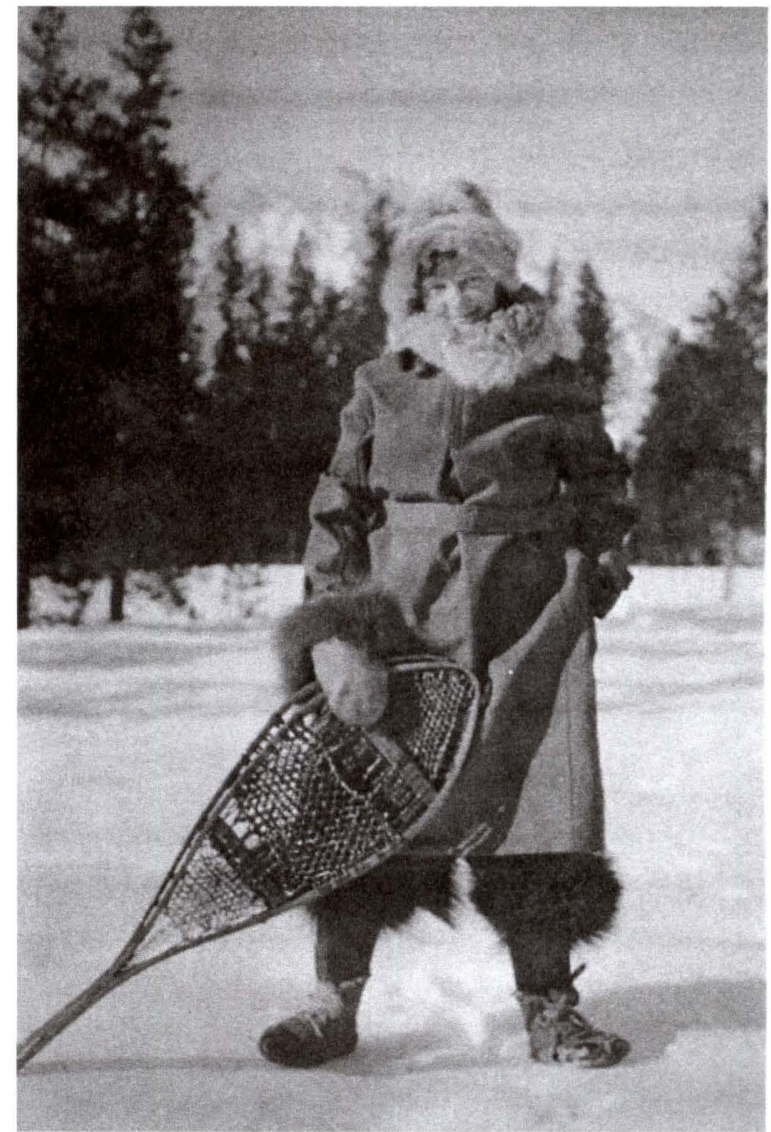

Figure 8. Hildegard Crandall with snowshoes ca. 1920's (C) Crandall) 
Hank took a job with the U.S. Biological Survey in Boise, Idaho, just long enough to buy a Model T Ford. The Model T provided the means to fulfill his childhood dream of visiting the Teton Mountains (Crandall, Hildegard 1970). During the summer of 1920, Hank and Hilda took off on a two week adventure through Yellowstone National Park. On their return route, they traveled through Teton country. In order to get the Model $\mathrm{T}$ over the Teton Pass, they had to push it up the steep switchbacks (Crandall, Hildegard 1983).

Hank and Hilda were married in October of 1921 (Crandall, Hildegard 1980). The newlyweds moved to Pocatello, Idaho, where Hank opened a commercial sign shop, and Hildegard took a secretarial job at a bank (Crandall, Hildegard 1983). However, the Crandalls did not reside in Pocatello for long as they were saving money to move to the Tetons and Jackson Hole (Crandall, Hildegard 1983).

When spring arrived in 1922, Hank enclosed the back of the Model $\mathrm{T}$ with plywood so that they could carry all their belongings to their new life in Jackson Hole (Crandall and Crandall, 1976). They carried a complete camping outfit (Crandall, Hildegard 1983), and photographic supplies (Flood 1996). Hank and Hilda took their friends, Red Kelly and Miss Bye, along on their trip to Jackson Hole, and they spent the summer camping (Crandall and Crandall, 1976). Red Kelly served as Hank's photographic assistant, and with their canoe, they paddled across lakes, and hiked up into the Teton canyons (Crandall and Crandall 1976; Crandall, Hildegard 1980).

Hank and Hilda camped the entire summer of 1922, living in a tent, and moving from place to place in what is now the Grand Teton National Park, including Jenny Lake, String Lake and Jackson Lake (Crandall, Hildegard 1980). Hank's primary interest was to paint the Tetons, but the first summer was spent scouting for photographs (Crandall, Hildegard 1980). Hank did not know what the Tetons had in store for him since he was only a student artist, with no established "fame or fortune" (Crandall, Hildegard 1970).

Hank had a fine camera that was formatted for making real photo postcards-a "3A Special Eastman Kodak" (Crandall,
Hildegard 1970). Photos of the mountains and valley were taken from every angle (Crandall, Hildegard 1980). Film and prints were developed at String Lake Camp, a fully equipped camp that was recently abandoned by a Hollywood film crew (Fig. 9). Hank used a canvas umbrella tent as a darkroom. His darkroom contained several plywood developing trays, which were made watertight by lining them with oil cloth. The negatives were mounted in wooden contact printing frames, and the photographic print paper was exposed through the negative by sticking the apparatus through the canvas flap for the appropriate dose of sunlight. Then, the film was developed and fixed in home mixed solutions. The prints were washed in String Lake and dried on tightly stretched bed sheets. Then, they were trimmed, stamped with "postcard" on the back, and sold at Charlie Fessler's General Store in Moran village. Selling postcards was a tenuous start, but Hank was optimistic about making a living selling his Teton art.

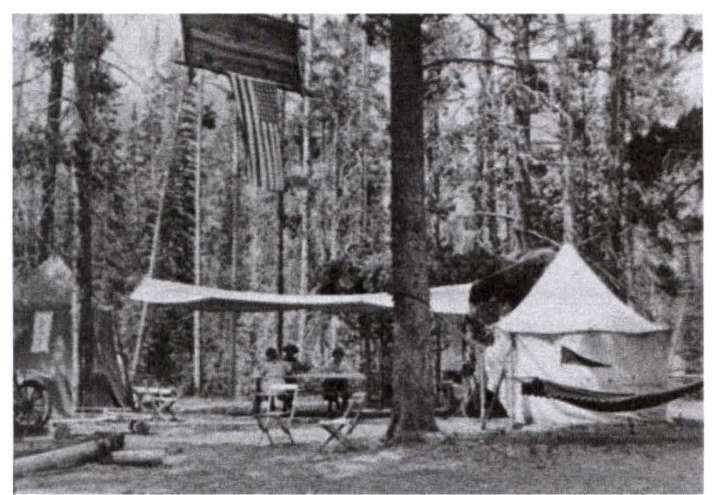

Figure 9. String Lake Camp ca. 1922 (C) Crandall)

By the fall of 1922, friends had persuaded Hank and Hilda to stay the winter at Moran village. Moran, located near the base of the Jackson Lake Dam, was a lively village, which consisted of Ben Sheffield's spacious main lodge surrounded by rustic cabins, a store, auto garage, campground and corral. Moran served as a camp for the construction crews that were working on Jackson Lake Dam, and as a stop for travelers. Charlie Fessler owned the Moran General Store, and he suggested a cabin for Hank and Hilda in exchange for cutting fuel wood and ice from Jackson Lake (Fig. 10) (Crandall and Crandall 1976; Crandall, Hildegard 1980). 
Hank negotiated a lease to open a studio and photo developing business at Moran village in the late 1920s. For more than 20 years, Hank operated a darkroom service where he and his apprentices would spend most evenings developing and contact printing film for the local dude ranch guests.

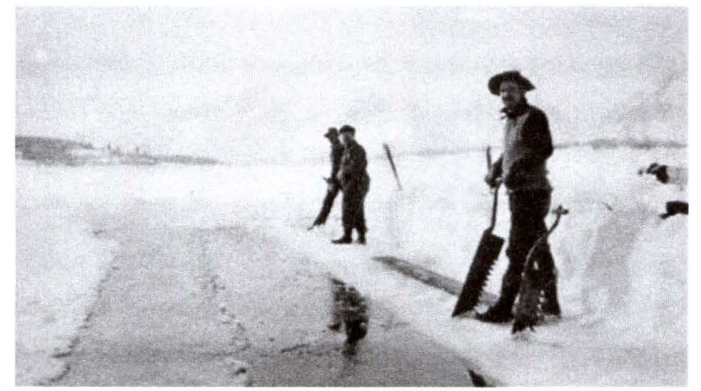

Figure 10. Hank Crandall cutting ice on Jackson Lake ca. 1922 (C) Crandall)

During their first winter at Moran, Hank and Hilda became well acquainted with the local homesteaders (Crandall, Hildegard 1980). On Saturday nights, they would meet with friends and attend a party at one of the nearby ranches. The party often began with a 10-mile long ride on a mail sleigh (a large horse drawn sled on four runners covered with canvas and containing a sheep herder's stove). At the ranch house, about 20 adults would play cards until midnight, and then the music started and folks danced until daybreak. The Crandall's often helped furnish the music-Hank played the trombone, and Hildegard played the piano.

Hank and Hilda went on a ski trip to take photographs in the spring of 1923. They visited Tony Grace who owned the Danny Ranch (now called the Jenny Lake Ranch), which was located close to String Lake (Crandall, Hildegard 1980). They learned that land adjacent to Danny Ranch was available for homesteading. Upon hearing the good news, Hank "ran as if there was fire back of him" and "hitched" a sleigh ride to the land office. They filed for a 120 acre homestead, which was located northeast of Jenny Lake (Crandall and Crandall 1976; Crandall, Hildegard 1983).

Hank and Hilda lived in a Sibley tent during their first summer on the homestead, complete with a wood-burning stove in the kitchen area (Crandall, Hildegard 1983). Later, they stayed in a larger tent in order to cook for $\log$ builders and carpenters (Crandall, Hildegard 1980). Building projects included a 2-room cabin, an art studio and a dance pavilion (Crandall, Hildegard 1980; Crandall, Hildegard 1983). The cabin was heated by a kitchen range, and a pot-bellied stove (Crandall, Hildegard 1980). A wash tub was set up in front of the stove for bathing. Kerosene lamps were used (Crandall and Crandall 1976). Most of the furniture was homemade — only Hildegard's piano was store bought (Crandall, Hildegard 1980).

In the summer, water for domestic use and photo processing had to be carried from String Lake. In the winter, snow was collected in a 50-gallon barrel, melted in big pots, and filtered through a cloth (Crandall, Hildegard 1980). Fresh vegetables could be purchased in Kelly, so no attempt was made to grow a garden (Crandall, Hildegard 1980). Also, Hank would "lay in" food and supplies from Idaho - anything that could be stored in a root cellar. Hank hunted game in order to provide meat for the family, but he did not enjoy hunting much, so it was usually put off until about the last day of the hunting season. Also, fresh meat could be purchased from a merchant, who delivered meat from Wilson to the nearby Danny Ranch. Hildegard tried to raise a few chickens, but the local wildlife ended up taking most of them (Crandall, Hildegard 1980).

Hank and Hilda were not ranchers, so they undertook several commercial ventures to provide a little income. In 1924, they opened the "String Lake Dance Pavilion" on the homestead (Crandall and Crandall 1976; Crandall, Hildegard 1980). The open-air dance hall had a 70-foot long floor made of lodgepole pine planks. The walls were lodgepole logs that extended about 4 feet off the floor, with the upper portion of the walls being canvas (Crandall and Crandall 1976; Crandall, Hildegard 1980). The Dance Pavilion was open for business during the summer months - from mid-June until the end of August (Crandall, Hildegard 1980). Hank and Hilda's musical talents were already in high demand throughout the valley. Their band consisted of Hank on trombone, Hilda on piano, Charlie Hedrick on fiddle, and Louie Flemming or Cliff Ward on the drums (Crandall and Crandall 1976; Crandall, Hildegard 1980; Crandall, Hildegard 1983). The Saturday night events were so popular that dances were added on Wednesdays. Square dancers came from miles around, and included valley residents and "dudes" from the local dude ranches. There 


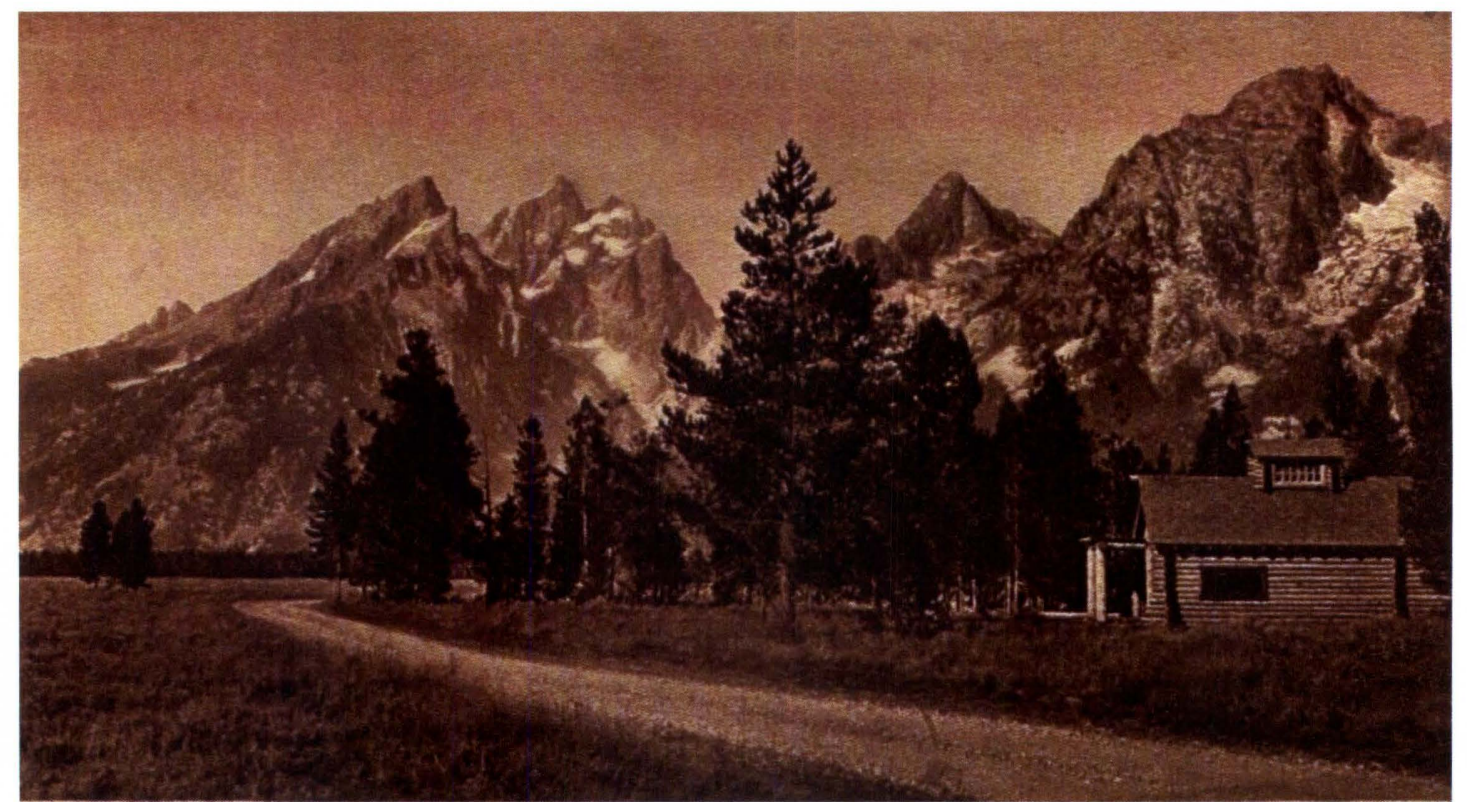

Figure 11. Crandall Studio building at the original homestead location

were few tourists, as the roads were not sufficiently improved. At midnight, around huge campfire, "lunch" was served, which included a sandwich, pie and coffee. After refreshments, folks danced until at least 2:00 a.m. (Crandall and Crandall 1976).

Hank took care of business during the day and played in the band at night. The dance pavilion was discontinued after about 2.5 years because Hank wanted to concentrate all resources on opening his art studio. In 1925 and 1926, wood from the pavilion was recycled and diverted to the construction of the Crandall Studio (Fig. 11) (Crandall, and Crandall 1976; Crandall, Hildegard 1980). The studio was conveniently located on the homestead near the road, but not too far from the cabin, so that regular staffing was not required (photo processing was being done at a small separate one-room structure). Hank designed the rustic lodgepole studio to withstand heavy winter snow loads, and outfitted the interior with a skylighted, detailed log pattern (Fig. 12). The structure was constructed entirely by local artisans (Q. Pownall personal communication 2007; H. Pownall personal communication 2007). Today, the studio building represents an enduring architectural statement, and is considered to be one of the landmark rustic buildings in Jackson Hole.

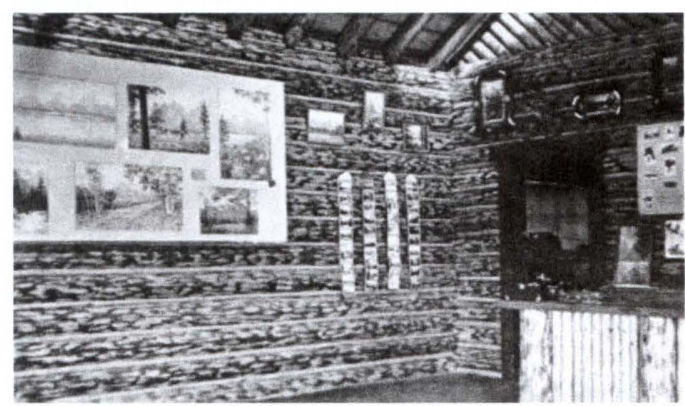

Figure 12. Interior of the Crandall Studio building ca. late 1920 's (C) Crandall)

In 1927, the Crandall studio was opened. Business depended on a few tourists and guests from the dude ranches. When a vintage car would approach, the noise was sufficient to announce the arrival of a potential customer. When a car would drive up, Hank would yell "Hrrrrrrry, Hrrrrrrrrry, biznessssss!" The studio door was always kept open (Crandall and Crandall 1976; Crandall, Hildegard 1980). In the early years, tourist traffic was extremely light, so there were few customers (Crandall, Hildegard 1980).

Hank also sold Kodak photo finishing for the local dude ranches (Crandall and Crandall 1976; Crandall, Hildegard 1983). When the studio first opened, Hank sold only the few photographs that he had taken the summers before. However, soon thereafter, Hank began hand painting his photographs, which became very popular in Jackson Hole (Crandall and 
Crandall 1976). Later, the studio sold paintings, post cards, photographs (sepia tone, black and white, and hand painted), cameras and film, poster prints, wood carvings of wild animals, animal skins (elk, bear and mountain lion), Navaho rugs, baskets, jewelry by western artisans and guidebooks (H. Pownall personal communication 2007; Q. Pownall personal communication 2008). Care was taken to offer a finer quality of souvenirs-some were imported from Germany. There was also a small film changing darkroom. Hank did little of the actual salesmanship, leaving that to other members of the family and employees (Q. Pownall personal communication 2007; H. Pownall personal communication 2007). Hank also produced and sold several photo picture books of the Tetons, including "The Tetons in Pictures" (Crandall, Harrison ca. 1930) and "The Tetons in Color" (Crandall, Harrison 1953).

The winters were typically spent printing, developing and stamping the photographs that Hank had taken the previous summer. When photographic supplies arrived, they had to be carried in from Moran. The Crandalls would put on snowshoes-Hank would pull the toboggan and Hilda would push. Hildegard's secretarial skills were important for business correspondence and record keeping. Otherwise, she kept very busy braiding rugs, cooking and keeping the fires burning (Crandall and Crandall 1976).

Hank and Hilda spent a total of seven years on the homestead, although they did take trips out during the winter to explore other ways to make a living, as the postcard business was not very profitable (Crandall and Crandall 1976). In 1928, the Snake River Land Company offered to buy the homestead, and the Park tendered a twenty-year concession lease to operate a picture and curio shop at Jenny Lake. Hank and Hilda quickly accepted the offers. By selling the homestead, Hank retained his dream of having an art studio in the Tetons, and the proceeds made it possible to establish the studio business on a year-round basis (Crandall, and Crandall 1976; Crandall, Hildegard 1980; Crandall, Hildegard 1983). Hank and Hilda wintered that year in Jackson where life would be a little more comfortable. Thereafter, the Crandalls lived at their summer quarters in back of the Crandall studio at Jenny Lake, but over wintered outside of the valley. In 1932, and for 17 years thereafter, their winter home was in Boise, Idaho.

Hank and Hilda's first child, Quita, was born in Jackson, Wyoming, on 16 October 1928. Quita's natural artistic talents were recognized at an early age, and she went on to become an accomplished artist. During Quita's formative years, her father tutored her at the studio, and she was encouraged to draw and paint the wildflowers of the Tetons. Quita hand painted many of the Crandall photographs, especially the wildflower panels. She also served as a Crandall Studio salesperson, and, later, helped manage the Crandall Studio at Moran. Following her formal art education at Stephens College (Missouri) and the Pratt Institute (New York), she became a graphic artist for the University of Wyoming, and a freelance artist for commercial publications (ca. 1960-1968). Her main career in the fine arts began in 1970. Her favorite subjects include the scenic wonders of Wyoming, including landscapes, animals in wild settings, cowboys, ranchers and Native Americans. Quita, as she signs her paintings, has exhibited her oil and pastel paintings widely, and has received many art awards in Wyoming (Kovinick and Yoshiki-Kovinick 1998).

Quita married Herbert (Herb as he prefers) D. Pownall in 1950. Herb worked extensively with Hank in the darkroom as an apprentice. Herb's formal photographic training began with courses at Iowa State College, and his experience using Press Cameras during journalism assignments, but working in the Crandall darkroom turned out to be a rewarding experience for a young photographer. At the Crandall Studio, Herb had to learn Hank's unique, market tested techniques and standards, which were different than those provided by his collegiate courses (H. Pownall personal communication 2008). Quita and Herb managed the Crandall Studio at Moran from 1952 until the last summer of operation in 1954. The National Park Service removed the Moran village in 1955, and moved many of the cabins to Colter Bay (NPS 2007). Quita and Herb moved to Laramie, Wyoming, where Herb was employed by the University of Wyoming to set up the campus photographic service (H. Pownall personal communication 2008).

Hank and Hilda's second daughter, Nancy, was born during the summer of 1930 (Crandall, Hildegard 1980). Nancy also worked 
with her father in the studio by hand painting photographs and assisting in the darkroom. She was also a salesperson at the studio (Flood 1996; Q. Pownall personal communication 2008). Like her sister, Nancy went to Stephens College, but eventually graduated from the University of Wyoming. She went on to become a junior high school teacher. Nancy passed away in 1998 (Q. Pownall personal communication 2008).

After the founding of the Grand Teton National Park in 1929, Hank became the Park's "Official Photographer" (Flood 1996). The National Park Service negotiated Hank's concession based on the successful F.J. Haynes photographic concession in Yellowstone National Park (Q. Pownall personal communication 2007; H. Pownall personal communication 2007). The Crandall Studio was moved from its original location on the homestead to near the shore of Jenny Lake. Later, in about 1960, the studio was moved back a short distance from the Lake to its present location. The studio is listed on the National Register of Historic Places, and is currently a National Park Service visitor center (Q. Pownall personal communication 2007; H. Pownall personal communication 2007).

The Studio business was rather lean from 1932 until the mid-1940s because tourism was limited by the Great Depression and World War II, and the Grand Teton National Park's tourist trade was not well established (Crandall, Hildegard 1983). During these lean summers, Hank was able to spend more of his time painting (Crandall and Crandall 1976). Hank maintained a studio at his home in Boise, and during the long winters, he refined his art (Q. Pownall personal communication 2007).

In 1941, Hank and Hilda began building a new home and studio at "Paint Brush Point" near the north end of Blacktail Butte, just east of Moose, Wyoming. Paint Brush Point became the family's year-round home - complete with world-class views of the Tetons. Unfortunately, Hank's workshop at Paint Brush Point burned in late December of 1954, and most of his collection and photographic negatives were lost in the fire (Crandall, Hildegard 1980).

Hank retired in 1959, after operating his studio business for 34 years. He sold the Crandall Studio and Park business concession. In retirement, Hank had the time to focus on his oil painting - an activity he did not have sufficient time to take very seriously while running the business (Crandall, Hildegard 1970; 1980). Hank recovered from a serious illness and surgery in early 1969, and returned to painting. Hank passed away at Paint Brush Point on 14 December 1970 (Crandall, Hildegard $1970 ; 1980)$.

\section{$\uparrow \quad$ CONCLUSIONS}

Hank Crandall came to the Teton Range and Jackson Hole for reasons that were intensely personal- to live and work in the landscape that he loved. However, his lifetime achievement can now be viewed as transcending his personal story, or even his own generation. Hank left a legacy of National Park art that helped create an early vision of the Tetons that will continue to inspire and inform generations to come. The souvenirs sold in his studio gave countless National Park visitors a tangible remembrance of their trip or vacation. His unique hand painted photographs and oil paintings will continue to grace many fine American homes. His homestead will always remain preserved land at the heart of the Grand Teton National Park.

\section{ACKNOWLEDGEMENTS}

The project would not have been possible without the generous support of Quita and Herb Pownall, who provided valuable firsthand knowledge and insight. Quita and Herb also graciously provided access to numerous Crandall photographs. Alice Hart and Sue Consolo Murphy, of the Grand Teton National Park, provided assistance and encouragement. The University of Wyoming, UW-NPS Research Center, provided valuable support for the field work, including access to the facilities at the AMK Ranch. A special thanks goes to Henry (Hank) Harlow, Director of the UW-NPS Research Center, and the dedicated assistance of Celeste Havener, also of the UW-NPS Research Center. 


\section{$\downarrow$ Literature Cited}

Albright, H.M. 1971. Letter to the Editor, Jackson Hole News. January 7, 1971.

Crandall, Harrison R. 1953. The Tetons in Color. Hank R. Crandall, lithographed by Security Lithograph Company, San Francisco, California. $26 \mathrm{pp}$.

Crandall, Harrison R. ca. 1930. The Tetons in Pictures. Crandall Studios, Grand Teton National Park, lithographed by Graves \& Potter, Inc., Pocatello, Idaho. $75 \mathrm{pp}$.

Crandall, Hildegard. 1983. Diary of Our Adventures in Jackson Hole-Five Years on the Homestead. Signed written history document, October 5, 1983. Jackson Historical Society \& Museum, Jackson, Wyoming.

Crandall, Hildegard. 1980. Interview Summary. Jackson Historical Society \& Museum, Jackson, Wyoming.

Crandall, Hildegard. 1970. Compiled Notes Collected by H.D. Pownall for the Jackson Hole Guide. Jackson Historical Society \& Museum, Jackson, Wyoming.

Crandall, Hildegard and Crandall, Harrison R. 1976. Notes About Hildegard and Harrison. Jackson Historical Society \& Museum, Jackson, Wyoming.
Flood, E.C. 1996. Harrison R. Crandall Photographer. Cowboys \& Indians: The Premier Magazine of the West. Summer, 1996. pp. 49-54.

Jackson Hole News \& Guide. 2006. Show Stars One of $1^{\text {st }}$ Artists to Paint Tetons. June 14, 2006.

Kovinick, P. and M. Yoshiki-Kovinick. 1998. An Encyclopedia of Women Artists of the American West. University of Texas Press, Austin, Texas.

NPS (National Park Service). 2007. Grand Teton Historic Resource Study, Chapter 15: Tourists.

http://www.cr.nps.gov/history/online_books.

Pownall, Herbert. 1991. Notes on the Museum Qualities of Hank R. Crandall Photographs. Jackson Historical Society \& Museum, Jackson, Wyoming.

Pownall, Quita. 1991. Notes on the Crandall Family. Jackson Historical Society \& Museum, Jackson, Wyoming.

Winchell, T. 2007. Personal Communication. Owner, Fighting Bear Antiques, Jackson, Wyoming. 